\title{
ANÁLISE SOBRE A (IM)POSSIBILIDADE JURÍDICA DA USUCAPIÃO DE BENS PÚBLICOS DOMINICAIS: BREVES CONSIDERAÇÕES HERMENÊUTICAS
}

\author{
Aloísio Alencar Bolwerk ${ }^{1}$ \\ Graziele Cristina Lopes Ribeiro ${ }^{2}$
}

\section{RESUMO}

O presente trabalho analisa a possibilidade de atribuir maior funcionalidade aos bens públicos, especificamente no tocante aos bens públicos dominicais. Aborda-se a possibilidade de usucapião sobre propriedade públicas sem destinação, à luz da função social da propriedade. Assim analisa-se a relação existente entre o absolutismo constitucional que constitui a propriedade pública como intocável e o caráter social da função da propriedade. Conclui-se pela necessidade de uma releitura na concepção clássica da supremacia do interesse público sobre o particular para alargar a valoração da função social da propriedade garantindo-lhe maior efetividade e eficácia.

Palavras-chave: Posse, propriedade, bens públicos, usucapião, função social da propriedade.

\section{ANALYSIS ON THE LEGAL (IM)POSSIBILITY OF ADVERSE POSSESSION ON PUBLICS ASSETS WITHOUT VOCATION: BRIEF HERMENEUTICAL CONSIDERATIONS}

\begin{abstract}
The present work analyzes the possibility of share greater functionality to public goods, specifically with regard to public goods without vocation. It is approached the possibility of adverse possession on public property, without vocation, in light of the social function of the property. Thus, the relationship between constitutional absolutism that constitutes public property as untouchable and the social character of the function of property is analyzed. It is concluded that there is a need on re-reading the classic conception of the supremacy of the public interest over the particular to extend the estimation of the social function of the property certifying greater effectiveness and efficiency.
\end{abstract}

\footnotetext{
${ }^{1}$ Doutor em Direito Privado pela Pontifícia Universidade Católica de Minas Gerais. Professor Adjunto de Direito Constitucional da Universidade Federal do Tocantins - UFT e do CEULP/ULBRA. Coordenador do Curso de Direito da Faculdade Ciências Jurídicas de Paraíso do Tocantins. Advogado.

${ }^{2}$ Doutoranda em Direito pela Faculdade Autônoma de São Paulo, Mestre em Direito pela Universidade Católica de Brasília. Professora do Curso de Direito do Centro Universitário Luterano de Palmas - CEULP/ULBRA. Presidente da Comissão de Relações Internacionais da OAB/TO, Advogada.
} 
Keywords: Possession, property, publics assets, adverse possession, social function of property.

\section{INTRODUÇÃO}

Qualquer abordagem sobre a propriedade remete à exegese que busca acompanhar o embalo da mutação ${ }^{3}$ constitucional e das leis em consonância com os valores sociais que abraçam o instituto. Tal se processa porque o direito de propriedade encontra íntima ligação com a democracia e com o Estado de Direito.

É a partir das constantes interpretações lançadas sobre a propriedade que se viabiliza sua evolução construtiva. Amparada nos valores sociais de determinado espaço-tempo, sua leitura passou a ser promovida a fim de lhe atribuir a tonalidade jurídica a permeá-la no cenário circundante. Disto resulta que, hoje, afigura-se densa carga valorativa atribuída à funcionalidade da tutela material da propriedade. Valoração, esta, que despertou tanto no Direito como na sociedade um outro olhar interpretativo que, inserto num Estado Democrático de Direito, passa a levar em consideração a justiça distributiva, o equilíbrio e o bem comum.

Nesta senda, o problema aqui tratado gira em torno da análise hermenêutica sobre a propriedade e a devida carga axiológica a lhe atribuir constante vigor ajustado ao cenário fenomênico social em que se processa. Esta tentativa de (re)potencialização propicia compatibilidade entre o conteúdo jurídico a ser aplicado e as necessidades das demandas sociais, principalmente sob os aspectos patrimoniais de ordem coletiva, a exemplo dos econômicos, culturais e ambientais; mas sem perder de vista a natureza privada que lhe é inerente.

É a partir desta ideia valorativa que o presente trabalho fora construído, diante de metodologia dialética e que visa problematizar situação fática in concreto e cujo objetivo geral é atribuir maior funcionalidade e o operabilidade aos bens públicos, mormente os dominicais.

\section{DA POSSE E DA PROPRIEDADE: A CONTRIBUIÇÃO HERMENÊUTICA DE SAVIGNY E DE IHERING E A CRÍTICA CONTEMPORÂNEA DE RAYMOND SALEILLES E ANTONIO HERNANDEZ GIL}

\footnotetext{
${ }^{3} \mathrm{O}$ termo mutação não significa reforma legislativa, mas nova interpretação lançada sobre determinado instituto do Direito, sem que haja necessidade de modificação do texto constitucional ou legal.
} 
A depender do contexto histórico teorias sobre a posse e a propriedade foram formuladas, a exemplo do pensamento - ainda um tanto quanto restrito - desenvolvido por Friedrich Carl von Savigny (1779-1861), para quem a relação constituída em uma posse asseguraria tão-somente ao detentor o direito aos interditos possessórios e à usucapião, pois o fato de possuir puramente a coisa não poderia ser interpretado como propriedade.

Para teoria subjetiva, o corpus e o animus domini eram os elementos constitutivos da posse, de modo que esta subsistiria quando o possuidor sustentasse a intenção de ter a coisa para si. Daí compreender sua identificação apenas arrimada na intenção do indivíduo em ter a coisa, mesmo sabendo que não é seu dono.

A posse, para essa teoria, possui dois elementos: a) o corpus - elemento material ou objetivo da posse, constituído pelo poder físico ou de disponibilidade sobre a coisa; b) animus domini, elemento subjetivo, caracterizado pela intenção de ter a coisa para si, de exercer sobre ela o direito de propriedade. (TARTUCE, 2011, p. 759)

A contribuição construtivista da interpretação da posse em Savigny assenta-se na ideia da simples existência de uma relação de vontade em se tornar proprietário, o que pode ser vislumbrado no plano da realização jurídica do instituto da usucapião.

Já sob outra perspectiva possessória, e contrapondo-se ao pensamento subjetivista, Rudolf Von Ihering (1818-1892) apresentou a teoria objetiva, fazendo distinção entre a situação fática e a situação jurídica. Ao analisar, verificou que a posse está no exercício do poder de fato sobre a coisa a fim de exteriorizar os atos de proprietário sobre a mesma. Isto significa que o possuidor deve imprimir destinação econômica à coisa como se proprietário fosse.

[...] para a constituição da posse basta que a pessoa disponha fisicamente da coisa, ou que tenha a mera possibilidade de exercer esse contato. Esta corrente dispensa a intenção de ser dono, tendo a posse apenas um elemento, o corpus, como elemento material e único fator visível e suscetível de comprovação. (TARTUCE, 2011, pp. 759-760). 
A teoria sobre a posse de Ihering encerra em hermenêutica axiológica fundamentada na necessidade de se atribuir determinada finalidade à coisa, de modo a atender sua função social, que se manifesta, sobretudo, a partir do exercício da exploração econômica. Indubitavelmente, esta é a principal contribuição da teoria objetiva de Ihering, destinando funcionalidade social à propriedade, vez que o possuidor, ainda que diante de um poder de fato, possui também o direito de exteriorizar todas as ações visando a proteção da coisa e, consequentemente, sendo-lhe exigido que a explore economicamente.

O Direito Brasileiro abraçou esta teoria, que se verifica por meio da própria hermenêutica axiológica incidente sobre a função da propriedade ao lhe destinar atendimento aos fins sociais.

Mas a própria evolução construtivista da hermenêutica axiológica da posse supera àquelas outrora sedimentadas pelos autores clássicos. Na contemporaneidade, o Direito passa a imprimir outros princípios fundamentais, sobretudo o da utilização da posse para o trabalho e para a preservação ambiental e do patrimônio cultural. E, assim, outras construções axiológicas surgiram acerca da posse, na tentativa de desvencilhá-la da propriedade, contrapondo-se claramente à noção defendida pela teoria objetiva.

Ao fenômeno possessório fora dado outro prisma interpretativo a partir das teorias de Raymond Saleilles e Antonio Hernandez Gil. Teorias que ganharam volume ao enfatizar o caráter econômico e a função social da posse, aliados à nova concepção do direito de propriedade, que também deveria exprimir natureza funcional em seu bojo teleológico.

Saleilles trouxe nova concepção em relação à teoria de Ihering, pois, ao emaranhá-la por intenso valor econômico o autor promoveu sua reformulação, atribuindo-lhe natureza de apropriação econômica. O corpus se manifesta como "uma relação durável de apropriação econômica, uma relação de exploração da coisa a serviço do indivíduo” (ALVES, 1997, p. 236).

O autor distingue sua teoria das anteriores, assentando-a num grau intermediário. A posse traduz relação de apropriação econômica, restando a figura do possuidor como aquele que, sob o ponto de vista dos fatos, aparece como tendo o gozo independente e, ainda, como aquele que de todos tem uma relação de fato com a coisa, considerado, assim, a justo título, como senhor de fato da coisa (ALVES, 1997, p. 237).

A teoria econômica não se confunde com a apresentada por Ihering, pois, para este, a posse era condição à destinação econômica da propriedade que, por sua vez, consistia no usar, 
fruir e consumir (IHERING, 2005, passim). Para Saleilles, a relação econômica não representa somente um meio de incorporar o corpus à vontade interna, exteriorizada legalmente pela forma jurídica da propriedade, mas exige uma consciência social que se projeta externamente. A reflexão aponta para a legitimidade de proteção da posse, e não no sentido de arrimar ou robustecer o direito de propriedade, mas como um direito decorrente apenas da posse em si mesma (ALBUQUERQUE, 2002).

A leitura que o autor promove é de substituição do elemento anímico individual pela consciência social, reforçando, assim, os aspectos externos da posse, que passam a ganhar maior relevância para a identificação do possuidor. Portanto, não se deduz a posse a partir da propriedade, pois a posse [...] "refere-se a uma vontade do indivíduo que deve ser respeitada pela necessidade mesma de todos de apropriação e exploração econômica das coisas, desde que esta vontade corresponda um ideal coletivo, segundo os costumes e opinião pública” (ALBUQUERQUE, 2002, pp. 128-129).

O autor desvencilha a posse da propriedade, intentando atribuir caráter autônomo à questão possessória. Para tal, desmistifica a compreensão geral que atrela a posse à propriedade, como se sua proteção estivesse limitada a correspondente salvaguarda do direito de propriedade, como outrora solidificado pela doutrina objetiva. Ao contrário, justifica na própria posse a razão em si mesma, “porque ela representa os fins do 'organismo social', constituindo um vínculo econômico e social, decorrente de um estado normal do indivíduo na sua relação com a vida coletiva” (ALBUQUERQUE, 2002, p. 130).

Concernente à diferenciação entre possuidor e detentor, Saleilles também não se filiou ao posicionamento de Ihering, que deixava a cargo da lei esta distinção. Para o autor, em interpretação singular, “o critério para distinguir a posse da detenção é o de observação dos fatos sociais; há posse onde há relação de fato suficiente para estabelecer a independência econômica do possuidor” (ALVES, 1997, p. 237). Já deter a coisa “é exercer, sem dúvida, um senhorio de fato, mas não uma destinação econômica. Possuir é realizar uma destinação econômica das coisas de acordo com sua destinação individual” (ALVES, 1997, p. 239).

O mérito alcançado por esta teoria, de matiz sociológica, foi o de libertar a posse do direito de propriedade, "restituindo a sua finalidade econômica e social imanente e dependente apenas dos costumes sociais e das diferentes relações jurídicas que unem o homem à coisa que 
explora” (ALBUQUERQUE, 2002, pp. 126-127). Neste passo, o autor enfatiza o traço distintivo e peculiar da posse, qual seja: sua autonomia social e econômica.

Em linha de raciocínio semelhante, e buscando visão contemporânea do fenômeno possessório, Antonio Hernandez Gil (1969), ao apresentar sua proposta de estudo, analisou a posse como elemento imanente à sociedade.

Afirma ser a posse situação factual evidente no meio social, circunstância esta que corrobora para o estreito liame entre o instituto e os interesses da coletividade. A regulação possessória está intrinsecamente vinculada à realidade social. Tal vinculação se torna tão premente que o autor sustenta ser a posse um direito superior, e cuja ligação ao seio social aufere tamanha densidade que termina por sobressair em relação aos demais direitos existentes (GIL, 1980, passim).

A proposta de Gil, que reconhece singularidade do direito à posse, almeja, em verdade, atingir pensamento destinado à emancipação possessória do instituto da propriedade. Por esta razão, seu estudo se distancia e se opõe aos estudos possessórios enfrentados nas teorias de Savigny e Ihering.

Se em Ihering a posse é a aparência da propriedade, e, para Savigny, a posse está atrelada à propriedade, em Gil, para configuração da existência de uma relação possessória ressalta-se que não se trata de mera detenção - é indispensável o animus de querer ser proprietário, pois a propriedade materializa-se no plano psicológico do agente, de inclinação individual em ser proprietário da coisa.

Noutros termos, enquanto Savigny atrela a relação possessória ao direito de propriedade e Ihering despreza a intenção do querer ser proprietário, em Gil o elemento volitivo passa a ser exaltado e representa o marco característico da posse (1980, p. 72).

Sobre as teorias objetiva e subjetiva, o autor aduz que a propriedade configura o ponto de contato entre ambas. Embora se apresentem antagônicas, entre elas há ponto de conexão, qual seja: a necessidade da figura da propriedade para entender o instituto da posse. E, em relação a este liame, aponta crítica no sentido de se atrelar a posse, e mesmo minimizá-la enquanto garantia à propriedade, vez que se trata de direito singular, primário e que precede à propriedade; atinge, assim, status de necessidade básica de apropriação (GIL, 1980, p. 72). 
Esta ideia se sustenta no fato de que o fenômeno humano e social do uso e da utilização das coisas é anterior ao processo de institucionalização da propriedade privada. A posse assume densidade social primária presente em qualquer sistema de convivência.

Nota-se o salutar traçado hermenêutico valorativo que o autor imprime em sua teoria, e que será aqui utilizado como base para esboçar o compasso jurídico que a propriedade carrega, socialmente analisada e funcionalmente interpretada. É para este sentido que o Texto Constitucional aponta, dispondo em várias passagens sobre a propriedade e sua vinculação social. Isto é o que se observa quando a Constituição estabelece não apenas a função da propriedade em si, mas também a função social da cidade e a função ecológica ${ }^{4}$.

\section{A FUNÇÃO SOCIAL DA PROPRIEDADE E A (IM)POSSIBILIDADE JURÍDICA DA USUCAPIÃO DE BENS PÚBLICOS DOMINICAIS: POR UMA TEORIA HERMENÊUTICA DE BASE AXIOLÓGICA}

Fruto da segunda dimensão dos direitos fundamentais, a propriedade ganha corpo e passa a entrelaçar-se com o rol dos direitos coletivos. Ao diligenciá-la por meio de normas, o Estado busca dar destinação aos bens, observando o respeito ao exercício da liberdade de propriedade assegurada a terceiros.

\footnotetext{
${ }^{4}$ Art. $5^{\circ}[\ldots .$.$] XXIII - a propriedade atenderá a sua função social. Art. 170. A ordem econômica, fundada na$ valorização do trabalho humano e na livre iniciativa, tem por fim assegurar a todos existência digna, conforme os ditames da justiça social, observados os seguintes princípios: [...] II - propriedade privada; III - função social da propriedade. Art. 182. A política de desenvolvimento urbano, executada pelo Poder Público municipal, conforme diretrizes gerais fixadas em lei, tem por objetivo ordenar o pleno desenvolvimento das funções sociais da cidade e garantir o bem-estar de seus habitantes. [...] § $2^{\circ}$ A propriedade urbana cumpre sua função social quando atende às exigências fundamentais de ordenação da cidade expressas no plano diretor. Art. 184. Compete à União desapropriar por interesse social, para fins de reforma agrária, o imóvel rural que não esteja cumprindo sua função social, mediante prévia e justa indenização em títulos da dívida agrária, com cláusula de preservação do valor real, resgatáveis no prazo de até vinte anos, a partir do segundo ano de sua emissão, e cuja utilização será definida em lei. Parágrafo único. A lei garantirá tratamento especial à propriedade produtiva e fixará normas para o cumprimento dos requisitos relativos a sua função social. Art. 186. A função social é cumprida quando a propriedade rural atende, simultaneamente, segundo critérios e graus de exigência estabelecidos em lei, aos seguintes requisitos: I - aproveitamento racional e adequado; II - utilização adequada dos recursos naturais disponíveis e preservação do meio ambiente; III - observância das disposições que regulam as relações de trabalho; IV - exploração que favoreça o bem-estar dos proprietários e dos trabalhadores. Art. 225. Todos têm direito ao meio ambiente ecologicamente equilibrado, bem de uso comum do povo e essencial à sadia qualidade de vida, impondo-se ao Poder Público e à coletividade o dever de defendê-lo e preservá-lo para as presentes e futuras gerações. $\S 1^{\circ}$ Para assegurar a efetividade desse direito, incumbe ao Poder Público: [...]VII - proteger a fauna e a flora, vedadas, na forma da lei, as práticas que coloquem em risco sua função ecológica, provoquem a extinção de espécies ou submetam os animais a crueldade (grifo nosso).
} 
Desta forma, a limitação na propriedade, tanto negativa quanto impositiva, com seus respectivos deveres e ônus, consolida a concepção de propriedade funcional a atender interesses não apenas particulares, mas, sobretudo, sociais. A função da propriedade e o consequente exercício da posse passam a ser alinhavados a outros princípios, como os de ordem econômica, ambiental e de segurança.

Também é para este sentido que o Código Civil aponta ${ }^{5}$. Disciplina proteção à propriedade, resguarda os direitos privados do proprietário, mas sem desvencilhá-los de ordem axiológica maior, a permear um mundo circundante aberto e robusto de valores e princípios outros a lhe compor e atribuir funcionalidade num plano cooperado, jurídico e, mesmo, pedagógico. Ter a propriedade é saber usá-la, não apenas em benefício próprio, mas também numa atmosfera abstrata de realização.

Nota-se que a evolução construtivista impressa ao princípio da função social da propriedade exige novo paradigma de valores, que buscam adequá-los aos novos contornos de sociedade pós-moderna, assim analisada sob a perspectiva solidária e fraterna, cuja atuação se perfaz num espaço-tempo comunicativo cooperado.

É envolvido nesta dinâmica de enredo que a função social se (re)potencializa e passa a ser interpretada como elemento otimizador e intrínseco da propriedade, vez que não pode haver propriedade sem destinação social.

Também corrobora com este entendimento a ordem jurídico-urbanística, assentada no Estatuto da Cidade, Lei $\mathrm{n}^{\circ} 10.257 / 2001^{6}$, que passou a regular o uso da propriedade urbana em prol do bem coletivo, do equilíbrio, segurança e do bem-estar dos cidadãos. Externou interesse legítimo do Estado em adotar política urbana responsável pelo pleno desenvolvimento das funções sociais da cidade e da propriedade urbana.

\footnotetext{
${ }^{5}$ Art. 1.228. O proprietário tem a faculdade de usar, gozar e dispor da coisa, e o direito de reavê-la do poder de quem quer que injustamente a possua ou detenha. $\S 1^{\circ} \mathrm{O}$ direito de propriedade deve ser exercido em consonância com as suas finalidades econômicas e sociais e de modo que sejam preservados, de conformidade com o estabelecido em lei especial, a flora, a fauna, as belezas naturais, o equilíbrio ecológico e o patrimônio histórico e artístico, bem como evitada a poluição do ar e das águas. Art. 2.035. [...] Parágrafo único. Nenhuma convenção prevalecerá se contrariar preceitos de ordem pública, tais como os estabelecidos por este Código para assegurar a função social da propriedade e dos contratos.

${ }^{6}$ Art. $1^{0}$ [...]. Parágrafo único. Para todos os efeitos, esta Lei, denominada Estatuto da Cidade, estabelece normas de ordem pública e interesse social que regulam o uso da propriedade urbana em prol do bem coletivo, da segurança e do bem-estar dos cidadãos, bem como do equilíbrio ambiental. Art. 39. A propriedade urbana cumpre sua função social quando atende às exigências fundamentais de ordenação da cidade expressas no plano diretor, assegurando o atendimento das necessidades dos cidadãos quanto à qualidade de vida, à justiça social e ao desenvolvimento das atividades econômicas, respeitadas as diretrizes previstas no art. $2^{\circ}$ desta Lei.
} 
[...] a Constituição de 1988 e o Estatuto da Cidade propõem é uma mudança de "olhar", substituindo o princípio individualista do Código Civil pelo princípio das funções sociais da propriedade e da cidade. Com isso estabelecem-se as bases de um novo paradigma jurídicopolítico que controle o uso do solo e o desenvolvimento urbano pelo poder público e pela sociedade organizada. (FERNANDES, 2010, p. 61).

A Lei aponta para novo sentido, o de que os interesses do proprietário devam coexistir com um conjunto de interesses sociais, históricos, ambientais e culturais. Para Francisco Cardozo Oliveira (2006, passim), o conceito de propriedade não se perfaz sem o conteúdo meritório que a função social abraça. O conceito de propriedade funcionalizada não depende apenas de uma formulação teórica abstrata, sem relação com os valores da realidade social e histórica em que é inserido o exercício dos poderes proprietários.

A utilidade social do uso da coisa que a funcionalização tutela é valor integrado à concretude do mundo que, obviamente, transcende os limites do conceito. O princípio da função social, portanto, direciona o conceito de propriedade para a recepção de valores ligados à realidade social e histórica em que inseridos a situação proprietária concreta e o conflito entre proprietários e não-proprietários. É através do princípio que se supera a concepção individualista de propriedade que evolui para a ideia de propriedade que considera a dinâmica da vida em sociedade.

Para a consecução desta abordagem sobre a propriedade é preciso estabelecer diálogo entre teoria e prática. Assim, faz-se necessário aproximar o saber teórico, que ilustra, conceitua e apresenta o instituto, mas em consonância com sua efetiva aplicação, isto é, sua real operacionalização. Ora, não é no plano teórico que a propriedade produz seus efeitos, mas sim no plano prático de realização a fim de ensejar verdadeira funcionalidade em seus variados desdobramentos, seja numa funcionalidade socioambiental, socioeconômica ou sociocultural. Em outras linhas, é no plano concreto de materialização que se pode perceber os efeitos funcionais da propriedade, e não na teoria meramente esboçada, carente de demonstração factual. 
A função social é princípio basilar do Estado e da democracia. É princípio que fomenta a ação solidária e cooperada, que possibilita maior distribuição de renda e incita o equilíbrio econômico e social a partir do senso de justiça distributiva. É princípio ímpar que, ao mesmo tempo, consegue carregar densa carga de justiça sem perder a segurança necessária. Como dizer que algo está errado, se se mostra funcional, se gera renda e riqueza, se distribui e faz-se operar em enredo cooperado a repartir e solidarizar as coisas em si? Este é o frutífero resultado da junção entre o justo, sem perder o resguardo do que se mostra seguro.

É da aliança entre o saber teórico e o saber prático que se atinge este resultado. $\mathrm{Na}$ adequação, encontra os valores sociais circundantes, a reclamar pela e em prol da funcionalidade, e na realidade, encontra experiência jurídica engessada, que de certa forma atravanca a realização material da função da propriedade. Esta crítica não se assenta apenas para a propriedade privada, improdutiva e disfuncional, onde o proprietário não enxerga na posse a concretude que se espera para produzir reflexos de justiça distributiva, mas também para a propriedade pública, para os bens públicos sem destinação alguma, inservíveis e que se apresentam apenas como mero patrimônio estatal acumulado, mas não gerenciável.

O Estado, enquanto sujeito que deveria dar o exemplo, encerra postura omissa - para não dizer irresponsável - quanto à administração de seus bens. Muitos sem destinação nenhuma, a exemplo dos bens dominicais ${ }^{7}$. Ainda que sem qualquer propósito social, são bens públicos que encontram expressa vedação constitucional para serem usucapidos. Assim dispõem o $\S 3^{\circ}$, art. 183 e o parágrafo único do art. 191, CF/88, quando da política urbana e fundiária, que trazem restrição à usucapião dos imóveis públicos. O Código Civil reforça ao estabelecer no art. 102 a mesma teleologia.

Não se está a fazer mensuração sobre os bens de uso comum do povo ou reservados ao uso especial da Administração Pública, mas quanto aos bens dominicais que não se destinam à

\footnotetext{
${ }^{7}$ Art. 98. São públicos os bens do domínio nacional pertencentes às pessoas jurídicas de direito público interno; todos os outros são particulares, seja qual for a pessoa a que pertencerem. Art. 99. São bens públicos: I - os de uso comum do povo, tais como rios, mares, estradas, ruas e praças; II - os de uso especial, tais como edifícios ou terrenos destinados a serviço ou estabelecimento da administração federal, estadual, territorial ou municipal, inclusive os de suas autarquias; III - os dominicais, que constituem o patrimônio das pessoas jurídicas de direito público, como objeto de direito pessoal, ou real, de cada uma dessas entidades. Parágrafo único. Não dispondo a lei em contrário, consideram-se dominicais os bens pertencentes às pessoas jurídicas de direito público a que se tenha dado estrutura de direito privado. Art. 100. Os bens públicos de uso comum do povo e os de uso especial são inalienáveis, enquanto conservarem a sua qualificação, na forma que a lei determinar. Art. 101. Os bens públicos dominicais podem ser alienados, observadas as exigências da lei. Art. 102. Os bens públicos não estão sujeitos a usucapião (grifo nosso).
} 
atividade alguma. Ora, o que justifica essa proteção patrimonial absoluta a incidir, inclusive, sobre bens que não se prestam, direta ou indiretamente, a nenhuma funcionalidade? O óbice, que encontra forte respaldo constitucional, nada mais é do que uma visão imperialista de gestão e de governo, calcada numa ideia irrestrita de propriedade pública intocável.

Esta restrição do Estado, calcada em sua autoridade, mais se aproxima do abuso de poder do que de proteção e resguardo dos bens públicos. Sem qualquer cerimônia, abusa do gozo do direito de ser proprietário, alegando norma constitucional impeditiva.

Ora, o Estado pode alienar os bens públicos dominicais. Trata-se da inalienabilidade relativa dos bens públicos em si, cuja previsão está assentada no art. 101 do CC/02. Por meio de leis, no âmbito das competências municipais, estaduais, distritais ou federais, pode realizar alienações sob a forma de doações de lotes e terrenos para atender seus interesses. Pode fazer concessão de uso especial para fins de moradia, nos termos da Medida Provisória nº 2.220 (são os casos dos conglomerados familiares que se formam nas favelas).

Mas autorizar a prescrição constitutiva de seus bens dominicais - que não se prestam a qualquer fim -, disto não cuida. Lança seu olhar atravessado ao instituto da usucapião, como se fosse uma ofensa ou agressão moral qualquer ação judicial que vise a declaração deste direto. Aos particulares entre si imputa esta possibilidade, mas não volve o mesmo enredo jurídico para si. Quando do não atendimento das funções sociais da propriedade privada urbana ou rural, desapropria, mas é incapaz de prever a possibilidade jurídica de uma auto-desapropriação ${ }^{8}$, por não querer enxergar desvios funcionais em muitos de seus bens.

Realmente, os valores que o Estado imprime ao princípio da função social da propriedade vão na contramão dos valores almejados pela sociedade, principalmente no que tange a satisfação de seus interesses - por sinal, públicos. Se o princípio da eficiência rege a Administração Pública, resta muito ineficiente a atuação estatal quanto à funcionalidade de seus bens.

Se à propriedade tem que ser dada alguma destinação, tal só se faz por meio da posse, pois é a posse que operacionaliza a função social de uma propriedade. A propriedade existe no plano jurídico, a identificar o direito do portador de exercer o domínio sobre um bem. Já a posse é

\footnotetext{
${ }^{8}$ Claro que a auto-desapropriação não é instituto jurídico, e nem poderia, pois o Estado não pode praticar atos contrários ao seu patrimônio, pelo menos não no plano da legalidade. É que a passagem acima serve como um reforço à crítica aos atos de gestão estatal.
} 
factual, situacional. Enquanto a propriedade é adquirida (transferência do domínio), a posse é constituída, justamente por se tratar de uma relação de fato ${ }^{9}$. Ora, o Estado se faz proprietário, senhor, mas - em muitas ocasiões - não se mostra possuidor, porque incapaz de atribuir funcionalidade ao que não se presta a nada, ou que, ainda que se preste, não é dada qualquer destinação. Isto é o ocorre com muitos dos bens dominicais, que sob o domínio do acervo patrimonial do Estado não encontram funcionalidade a lhes ser atribuída.

Os bens dominicais são bens que pertencem ao patrimônio disponível do Estado, ou seja, estão à sua livre disposição, seja porque não se destinam ao público em geral, seja porque não "são utilizados para o desempenho normal das atividades administrativas" (CARVALHO FILHO, 2012, p. 1133). Enquadram-se aqui os bens imóveis, a exemplo de terras ${ }^{10}$ e terrenos sem destinação pública específica e os prédios públicos desativados, bem como os bens móveis que não se prestam a nenhum fim ou restam inservíveis às atividades administrativas.

Noutro ponto, para que os bens públicos sejam enquadrados enquanto dominicais, há que se levar em conta sua afetação ou desafetação. Assim, no que toca os fins para os quais estão sendo utilizados, "se um bem está sendo utilizado para determinado fim público, seja diretamente do Estado, seja pelo uso dos indivíduos em geral, diz-se que está afetado a determinado fim público. [...] o bem se diz desafetado quando não está sendo usado para qualquer fim público” (CARVALHO FILHO, 2012, p. 1133, grifo do autor). O bem desafetado, portanto, não é utilizado para nenhum tipo de atividade administrativa normal. “Afetação e desafetação são os fatos administrativos dinâmicos que indicam a alteração das finalidades do bem público” (CARVALHO FILHO, 2012, p. 1133, grifo do autor). Um bem público pode deixar de ser afetado para ser desafetado, destituindo-o de sua natureza funcional, como também pode deixar a condição de desafetação para afetação, ganhando, assim, alguma destinação ou utilização pública.

Como se nota, os bens públicos dominicais são bens que estão à livre disposição do Estado, não lhes sendo reservado qualquer finalidade ou utilização, seja direta ou indireta. Assim, os

\footnotetext{
${ }^{9}$ Neste sentido, Fiuza.

${ }^{10}$ As terras devolutas são parte do acervo patrimonial dos bens dominicais. Todavia, tais terras não se ajustam à proposta aqui lançada de possibilidade de usucapião desses bens, desde que não se enquadrem nos termos do art. 20, II, CF/88 (bens da União), ou seja, desde que "indispensáveis à defesa das fronteiras, das fortificações e construções militares, das vias federais de comunicação e à preservação ambiental, definidas em lei”. Pelo princípio da simetria ou do paralelismo, o mesmo entendimento se estende às terras devolutas dos EstadosMembros e dos Municípios.
} 
bens dominicais correspondem ao acervo patrimonial dos bens desafetados, vez que estão suscetíveis aos atos de mera disposição da vontade estatal, não lhes restando qualquer destinação ou função específica.

Ponto importante reside sobre o ato de afetação ou de desafetação. Celeuma existente quanto à sua formalidade ou informalidade. Para José dos Santos Carvalho Filho, acompanhando a doutrina administrativista majoritária,

[...] deve-se destacar que a afetação e a desafetação constituem fatos administrativos, ou seja, acontecimentos ocorridos na atividade administrativa independentemente da forma com que se apresentem. Embora alguns autores entendam a necessidade de haver ato administrativo para consumar-se a afetação ou a desafetação, não é essa a melhor doutrina em nosso entender. O fato administrativo tanto pode ocorrer mediante a prática de ato administrativo formal, como através de fato jurídico de diversa natureza. Significa que, até mesmo tacitamente, é possível que determinada conduta administrativa produza a afetação ou a desafetação, bastando, para tanto, verificar-se no caso o real intento da Administração. (2012, p. 1134)

Para o autor, não importa o modo como se processou a afetação ou a desafetação, o que realmente importa é o fato gerador ou a ocorrência em si que gerou a alteração da finalidade do bem público (2012, 1134). Razão assiste neste ponto, até porque o Poder Público, amparado no mérito administrativo, pode praticar, formalmente, atos de afetação ou desafetação, quando assim o interesse discricionário se manifestar. Mas justamente pela ideia de conveniência e de oportunidade é que não se pode deixar somente ao crivo da Administração esta questão, pois, ainda que materialmente desafetado, em razão de fato administrativo, resta inócuo por conta de omissão do Poder Público, que não mostra interesse na formalização da desafetação do bem.

No que tange a possibilidade de usucapião de bens públicos dominicais, independente de ato que formaliza a desafetação, restam passíveis de sofrer a prescrição constitutiva, vez que para estas hipóteses encontra-se relativizada a imprescritibilidade. Resumidamente, o fundamento jurídico está amparado na valoração da posse, que, devidamente estimulada, atribui funcionalidade à propriedade. 
A partir de base valorativa, lançam-se agora argumentos de ordem principiológica e valorativa para se arrimar esta possibilidade jurídica.

O direito de propriedade e o princípio da função social da propriedade vêm estampados, respectivamente, nos incisos XXII e XXIII do art. $5^{\circ}$ da CF/88 - erigidos assim à categoria de direitos e garantias fundamentais. Quanto à função social, trata-se de norma de eficácia plena ${ }^{11}$, cuja aplicação é direta e imediata, não dependendo de lei posterior a especificar os seus efeitos, assim como também não pode ter seu alcance restringido por norma infraconstitucional. Já o direito de propriedade é norma constitucional, mas de eficácia contida. Ainda que de aplicação direta e imediata, tem seu alcance limitado, seja por norma infraconstitucional, seja por norma constitucional. É o que acontece com a propriedade, que encontra limitação não apenas em leis, mas, sobretudo, na função social, vez que seu gozo está adstrito à funcionalidade que lhe é destinada. A função social, sob este aspecto, atua enquanto princípio a exercer operacionalidade sobre o direito de propriedade.

Ora, a função social da propriedade é norma de eficácia plena, independe de lei ou ato normativo da Administração Pública que venha a desafetar determinado bem. Se é dominical, por sua natureza, não se presta a finalidade alguma, resta disfuncional. Se assim o é, seja por ato ou por fato administrativo, não abraça qualquer destinação, razão pela qual, em preenchendo os requisitos, poderá ser usucapido ${ }^{12}$.

\footnotetext{
${ }^{11}$ Quanto às normas constitucionais, neste trabalho fora utilizada a classificação de José Afonso da Silva.

${ }^{12}$ Via de regra, os requisitos da usucapião são: posse pacífica, contínua, ininterrupta, pública e revestida com animus domini. O Código Civil estabelece as espécies e os requisitos específicos nos seguintes artigos: Art. 1.238 (usucapião extraordinária). Aquele que, por quinze anos, sem interrupção, nem oposição, possuir como seu um imóvel, adquire-lhe a propriedade, independentemente de título e boa-fé; podendo requerer ao juiz que assim o declare por sentença, a qual servirá de título para o registro no Cartório de Registro de Imóveis. Parágrafo único (primeira parte - usucapião extraordinária habitacional). O prazo estabelecido neste artigo reduzir-se-á a dez anos se o possuidor houver estabelecido no imóvel a sua moradia habitual, ou nele realizado obras ou serviços de caráter produtivo (segunda parte - usucapião extraordinária pro labore). Art. 1.239 c/c art. 191, CF/88 (usucapião constitucional pro labore). Aquele que, não sendo proprietário de imóvel rural ou urbano, possua como sua, por cinco anos ininterruptos, sem oposição, área de terra em zona rural não superior a cinqüenta hectares, tornando-a produtiva por seu trabalho ou de sua família, tendo nela sua moradia, adquirir-lhe-á a propriedade. Art. 1.240 c/c art. 183, CF/88 (usucapião constitucional habitacional pro morare ou pro misero). Aquele que possuir, como sua, área urbana de até duzentos e cinqüenta metros quadrados, por cinco anos ininterruptamente e sem oposição, utilizando-a para sua moradia ou de sua família, adquirir-lhe-á o domínio, desde que não seja proprietário de outro imóvel urbano ou rural. Art. 1.240-A (usucapião familiar). Aquele que exercer, por 2 (dois) anos ininterruptamente e sem oposição, posse direta, com exclusividade, sobre imóvel urbano de até $250 \mathrm{~m}^{2}$ (duzentos e cinquenta metros quadrados) cuja propriedade divida com ex-cônjuge ou excompanheiro que abandonou o lar, utilizando-o para sua moradia ou de sua família, adquirir-lhe-á o domínio integral, desde que não seja proprietário de outro imóvel urbano ou rural. Art. 1.242 (Usucapião ordinária ou comum). Adquire também a propriedade do imóvel aquele que, contínua e incontestadamente, com justo título e boa-fé, o possuir por dez anos. Parágrafo único (primeira parte - Usucapião ordinária habitacional). Será de
} 
Ainda que se possa argumentar sobre a ausência de norma, isto é, do ato administrativo formal para efetivar a desafetação do bem, o contra-argumento também recai sobre a função social, vista agora não como princípio, mas como cláusula geral a nortear a propriedade. E, enquanto cláusula geral, sua eficácia se perfaz a dar sentido funcional à propriedade, sendo dispensável qualquer ato normativo para tal. As cláusulas gerais no Direito assumem esse papel, porque ainda que abrangentes, quando manejadas, mostram-se pontuais a servir de normapadrão para atingir a operacionalidade que se espera quando da resolução do caso concreto. O enquadramento normativo em que estão contextualizadas já aponta para a significação que a cláusula pode abraçar.

Noutra banda, a imprescritibilidade do bem público pela usucapião está expressamente estampada no texto constitucional, nos arts. 183, $\S 3^{\circ}$ e 191, parágrafo único. O rigor constitucional foi estanque, não se importando em relativizar quanto aos bens públicos dominicais. Mas em que pese a barreira constitucional, advoga-se para a possibilidade da usucapião destes bens especificamente e principalmente quanto aos imóveis, cuja carga axiológica ganha outra amplitude no cenário social.

O argumento ora sustentado parte da axiologia em si, que visa apurar os valores circundantes e a forma como a realidade fenomênica se apresenta. Assim, para o enfrentamento do problema, faz-se necessário confrontar o inciso XXIII do art. 5º norma de eficácia plena, com os dispositivos constitucionais acima (arts. 183 e 191). A localização nevrálgica da celeuma, reside, justamente, no conflito aparente entre o princípio da função social da propriedade e o princípio da supremacia do interesse público sobre o particular.

cinco anos o prazo previsto neste artigo se o imóvel houver sido adquirido, onerosamente, com base no registro constante do respectivo cartório, cancelada posteriormente, desde que os possuidores nele tiverem estabelecido a sua moradia, ou realizado investimentos de interesse social e econômico (Segunda parte - Usucapião ordinária pro labore). Também, a Lei no $10.257 / 200$, estabelece a usucapião especial de imóvel urbano no art. $9^{\circ}$. Aquele que possuir como sua área ou edificação urbana de até duzentos e cinqüenta metros quadrados, por cinco anos, ininterruptamente e sem oposição, utilizando-a para sua moradia ou de sua família, adquirir-lhe-á o domínio, desde que não seja proprietário de outro imóvel urbano ou rural. E, por fim, a Lei no $6.969 / 81$, estabelece a usucapião especial de imóvel rural no art. $1^{\circ}$. Todo aquele que, não sendo proprietário rural nem urbano, possuir como sua, por 5 (cinco) anos ininterruptos, sem oposição, área rural contínua, não excedente de 25 (vinte e cinco) hectares, e a houver tornado produtiva com seu trabalho e nela tiver sua morada, adquirir-lhe-á o domínio, independentemente de justo título e boa-fé, podendo requerer ao juiz que assim o declare por sentença, a qual servirá de título para transcrição no Registro de Imóveis (grifo nosso). Procurou-se anotar tão-somente os casos de usucapião de bens imóveis em razão do impacto e do interesse axiológico que provocam no Direito e na sociedade. 
A partir da axiologia faz-se, então, análise destes princípios, para a qual é imprescindível a busca de sua teleologia a fim de se encontrar resposta jurídica fundamentada que possa pôr fim ao conflito. E, como se extrai do caso, os princípios apresentam teleologias distintas, que apontam para nortes diferentes.

A função da propriedade assume postura eminentemente social, cadenciada num espaço solidário e de arranjo democrático. Fomenta a erradicação da pobreza e uma sociedade livre, justa e equilibrada, de distribuição equânime de bens e riquezas. Esta é sua essência. Este é seu aporte epistemológico, que destaca a função social enquanto princípio tão perene no universo jurídico. Seu principal reflexo resulta numa justiça econômica distributiva inserta num espaço cooperado entre seus atores e entre sociedade e Estado. Ora, o Estado prega tanto por uma sociedade solidária, mas quando lhe é oportunizado prestá-la, é reticente, quando não, avesso.

Já a supremacia do interesse público sobre o particular encontra sua vazão na própria estrutura estatal. É princípio do Estado e para o Estado. Tal qual a reserva do possível, é princípio de proteção, quando não, de blindagem estatal. A abstração de seu conteúdo é menor do que a da função social e, além disto, por ser princípio a abastecer os interesses do Estado, seu círculo hermenêutico é singular, a formar quase que um fechamento operacional interpretativo que se direciona, na maioria das vezes, num único sentido, qual seja, atender o Estado.

\section{CONCLUSÃO}

Do juízo de valor acima articulado, depreende-se que a função social, em muito, se sobressai. Do que fora dito, também se extrai um juízo de realidade. E por realidade, deve-se lançar o olhar no social, no que toca as desigualdades em sentido lato, no que se refere ao desequilíbrio econômico pujante. Se a função social da propriedade busca amenizar este cenário, pela realidade que se apresenta, sua axiologia também assume maior relevo e contexto.

E, aos positivistas ortodoxos, que possam por ventura reagir ao enfrentamento acima esboçado, por meio de alegações e críticas dos mais diversos tons e estilos, a exemplo da completude do Direito, de sua harmonia e unidade normativa - claro que utópicas - volve-se a afirmação de que na Constituição há sim antinomias entre suas próprias normas, e o contra- 
argumento reside na ideia de existência no plano constitucional de normas constitucionais inconstitucionais ${ }^{13}$ - contra-argumento, este, calado na própria desarmonia sistêmica da Constituição.

Ora, do resultado do confronto acima exposto, resta interpretação que imprime à função social da propriedade maior envergadura valorativa em relação ao princípio da supremacia do interesse público sobre o particular. E não poderia ser diferente, ainda que do desenho acima arranjado enseje a falsa ideia de que a função social se presta a abastecer interesse privado; ao revés, no caso confrontado, o interesse por ela perscrutado longe está do raio da esfera particular, encontrando no interesse público maior efetividade e eficácia, o que eleva ainda mais sua envergadura num plano ideológico valorativo.

\section{REFERÊNCIAS}

ALBUQUERQUE, Ana Rita Vieira. Da função social da posse e sua consequência frente à situação proprietária. Rio de Janeiro: Lumen Juris, 2002.

ALEXY, Robert. Colisão de direitos fundamentais e realização de direitos fundamentais no estado de direito democrático. Revista de Direito Administrativo, Rio de Janeiro, n. 217, jul./set. 1999.

ALVES, José Carlos Moreira. Posse: evolução histórica. Rio de Janeiro: Forense, 1997.

AMARAL, Francisco. Direito Civil: introdução. $6^{\text {a }}$ ed. Rio de Janeiro: Renovar, 2006.

ARCELO, Adalberto Antonio Batista; GONTIJO, Lucas de Alvarenga. A Biopolítica nos Estados Democráticos de Direito: a reprodução da subcidadania sob a égide da constitucionalização simbólica. Belo Horizonte: Material aula Doutorado, 2013.

ARENDT, Hannah. A condição humana. Tradução de Roberto Raposo. $9^{\mathrm{a}}$ ed. Rio de Janeiro: Forense Universitária, 1999.

ARONNE, Ricardo. Direito civil-constitucional e a teoria do caos: estudos preliminares. Porto Alegre: Livraria do Advogado, 2006.

\footnotetext{
13 Teoria jurídica apresentada pelo jurista alemão Otto Bachof, precursor da defesa da possibilidade de existência de normas constitucionais inconstitucionais.
} 
AZEVEDO, Álvaro Villaça. Bem de Família: com comentários à Lei 8.009/90. $5^{\mathrm{a}}$ ed. São Paulo: Revista dos Tribunais, 2002.

BACHOF, Otto. Normas Constitucionais Inconstitucionais? Trad. e nota prévia de José Manuel M. Cardoso da Costa. Coimbra: Almedina, 1994.

BARROSO, Luís Roberto. Curso de direito constitucional contemporâneo. $2^{\mathrm{a}}$ ed. São Paulo: Saraiva, 2010.

BOLWERK, Aloísio A; LORENTINO, Sérgio Augusto Pereira. O direito civil sob a ótica pós-positivista: uma nova interpretação a partir da redefinição do conceito de liberdade. In: Roberto Senise Lisboa; Joyceane Bezerra de Menezes (Org.). Relações privadas e democracia. $1^{\mathrm{a}}$ ed. Florianópolis: FUNJAB, 2014, p. 125-142.

BOLWERK, Aloísio A.; VIEIRA, Murilo Braz. Considerações Hermenêuticas sobre a tutela da posse e da propriedade à luz da função social. Hermenêutica Jurídica. In: Enoque Feitosa Sobreira Filho; Rubens Beçak; Rodolfo Viana Pereira (Org.). $1^{\text {a }}$ ed. Florianópolis: CONPEDI, 2015, v. 1, p. 55-76.

BRASIL. Constituição (1988). Constituição da República Federativa do Brasil 1988. Organizado por Angher, Anne Joyce. 20ª ed. São Paulo: Rideel, 2015.

BRASIL. Lei $\mathbf{n}^{\mathbf{0}}$ 10.257, de 10 de julho de 2001. Disponível em <http://www.planalto.gov.br/ccivil_03/leis/leis_2001/110257.htm >. Acesso em: 20 mar. 2016.

BRASIL. Lei $\mathbf{n}^{\mathbf{0}}$ 10.406, de 10 de janeiro de 2002. Disponível em <http://www.planalto.gov.br/ccivil_03/leis/2002/l10406.htm>. Acesso em: 14 out. 2015.

BRASIL. Medida Provisória $n^{0}$ 2.220, de 04 de setembro de 2001. Disponível em <http://www.planalto.gov.br/ccivil_03/mpv/2220.htm>. Acesso em: 21 ago. 2016.

BRASIL. Lei $\mathbf{n}^{0}$ 6.969, de 10 de dezembro de 1981. Disponível em <http://www.planalto.gov.br/ccivil_03/leis/L6969.htm>. Acesso em: 11 set. 2016.

CARVALHO FILHO, José dos Santos. Manual de direito administrativo. 25a ed. São Paulo: Atlas, 2012.

DWORKIN, Ronald. Uma questão de princípio. Tradução de Luiz Carlos Borges. São Paulo: Martins Fontes, 2001.

FACHIN, Luiz Edson. A função social da posse e a propriedade contemporânea. Porto Alegre: Fabris, 1998.

FARIAS, Cristiano Chaves de; ROSENVALD, Nelson. Direitos Reais. $6^{\mathrm{a}}$ ed. Rio de Janeiro: Lumen Júris, 2010. 
FERNANDES, Edesio. O Estatuto da Cidade e a ordem jurídica-urbanística. In: O

Estatuto da Cidade comentado. CARVALHO, Celso Santos. ROSSBACH,

Anaclaudia (Org.). São Paulo: Ministério das Cidades, 2010.

FIUZA, C. A. C.; BOLWERK, Aloísio A. A interpretação do direito civil sob a ótica póspositivista. In: Elcio Nacur Rezende; Otavio Luiz Rodrigues Junior; José Sebastião de Oliveira (Org.). Direito civil contemporâneo. 1ed. Florianópolis: CONPEDI, 2015, v. 1, p. 100-120.

FIUZA, César. Direito civil: curso completo. 18ª ed. São Paulo: Revista dos Tribunais, 2015.

GIL, Antonio Hernández. La función social de la posesión: ensayo de teorización sociológicojurídica. Madrid: Alianza, 1969.

GIL, Antonio Hernández. La posesion. Madrid: Civitas, 1980.

GONÇALVES, Carlos Roberto. Direito civil brasileiro: responsabilidade civil. $5^{a}$ ed. São Paulo: Saraiva, 2010.

HÄBERLE, Peter. Hermenêutica Constitucional - A sociedade aberta dos intérpretes da constituição: contribuição para a interpretação pluralista e "procedimental” da constituição. Porto Alegre: Sergio Antonio Fabris Editor, 2002.

IHERING, Rudolf von. Teoria simplificada da posse. Tradução de Ricardo Rodrigues Gama. Campinas: Russell Editores, 2005.

KELSEN, Hans. Teoria Pura do Direito. Tradução de João Baptista Machado. $6^{a}$ ed. São Paulo: Martins Fontes, 1998.

KROHLING, A. A busca pela transdisciplinaridade nas ciências humanas. Revista de direitos e garantias fundamentais. Vitória, ES, n 2, p. 193-212, 2007.

MARTINS-COSTA, Judith; BRANCO, Gerson. Diretrizes teóricas do novo Código Civil brasileiro. São Paulo: Saraiva, 2002.

MIRANDA FILHO, Juventino Gomes de. A Função Social da Posse. In Estudos Avançados da Posse e dos Direito Reais. Belo Horizonte: Del Rey, 2010.

NEVES, Marcelo. A constitucionalização simbólica. São Paulo: Martins Fontes, 2011.

OLIVEIRA, Francisco Cardozo. Hermenêutica e tutela da posse e da propriedade. Rio de Janeiro: Forense, 2006

PASQUALINI, Alexandre. Hermenêutica e sistema jurídico: uma introdução à interpretação sistemática do direito. Porto Alegre: Livraria do Advogado, 1999. 
POPPER, Karl. A sociedade aberta e seus inimigos. Belo Horizonte: Itatiaia, 1998.

RAMOS, Carmem Lucia Silveira; TEPEDINO, Gustavo et al (Orgs.). Diálogos sobre o Direito Civil - Construindo a racionalidade contemporânea. Rio de Janeiro: Renovar, 2002. RAWLS, John. Uma teoria da justiça. São Paulo: Martins Fontes, 2008.

SARLET, Ingo Wolfgang. Dignidade da Pessoa Humana e Direitos Fundamentais na Constituição de Federal de 1988. $2^{\text {a }}$ ed. Porto Alegre: Livraria do Advogado, 2002.

TARTURCE, Flávio. Manual de direito civil. São Paulo: Método, 2011.

TEPEDINO, Gustavo. O Código Civil, os chamados microssistemas e Constituição: premissas para uma reforma legislativa. Disponível em <http://www.tepedino.adv.br/wp/wp-content/uploads/2012/09/biblioteca10.pdf>. Acesso em: 18 de jun. 2014. 